\title{
BUILDING DEMOCRACY WITHOUT DEMOCRATS? \\ Political Parties and Threats of Democratic Reversal in Nigeria
}

\section{Said Adejumobi \& Michael Kehinde}

\author{
Dr Said Adejumobi is Chief, Public Administration Section, \\ and Coordinator, Africa Governance Report, United Nations Economic \\ Commission for Africa \\ Governance and Public Administration Division, UNECA, \\ PO Box 3005, Addis Ababa, Ethiopia \\ Tel: +251912200066 e-mail: adesaid@yahoo.com \\ Michael Kehinde is a lecturer in the Department of Political Science, \\ Lagos State University \\ PM B 1087, Apapa, Lagos, Nigeria \\ Tel: +234 8025408439
}

\begin{abstract}
Political parties are not only a major agency for the recruitment and enthronement of political leaders in an electoral democracy they are the foundation and a building block of the process of democratic evolution and consolidation. However, the nature and character of the dominant political parties in Nigeria threaten the country's nascent democratic project. They lack clear ideological orientation, do not articulate alternative worldviews, rarely mobilise the citizenry, and basically adopt anti-democratic methods to confront and resolve democratic issues. Intra- and inter-party electoral competition is fraught with intense violence, acrimony and warfare. Put differently, these parties display all the tendencies and conduct of authoritarianism. The result is that what exists in Nigeria is 'democratism', the form and not the substance of an evolving democracy.
\end{abstract}

\section{INTRODUCTION}

The mass conversion of politicians and political thinkers to the cause of democracy has been one of the most dramatic, and significant, events in 
political history. Even in Ancient Greece, often thought of as the democratic ideal, democracy tended to be viewed in negative terms.

Thinkers such as Plato and Aristotle, for example, view democracy as a system of rule by the masses at the expense of wisdom and property. Well into the nineteenth century, the term continued to have pejorative implications, suggesting a system of 'mob rule'. Now, however, we are all democrats. Liberals, conservatives, socialist, communists, anarchists and even fascists are eager to proclaim the virtues of democracy and to demonstrate their own democratic credentials.

Haywood 1997, p 81

Democracy in Nigeria has had a chequered history. From the 'Wild-Wild West' experience of the First Republic through prolonged autocratic military regimes and the truncated Second and Third republics ${ }^{2}$ to the present democratic dispensation, democracy has suffered debilitating experiences in the country. The perennial travail of democracy is predicated on a number of factors, including ineffective structures and institutions, the foreboding presence of the military, corruption and money politics as well as the centrality of the state as the most important player in the economy. As such, whoever controls the state has at his/ her disposal a well-oiled money machine; hence, the contest for access to the apparatuses of state becomes a matter of life and death. Unfortunately, political parties in Nigeria are locked in the Hobesian war of 'every man against every man', negating the very essence of the party system in a democracy.

This paper is concerned with the role of political parties in the process of democratic (de)consolidation in Nigeria. We argue that the origin, orientation and activities of the parties are antithetical to the process of democratic consolidation. The parties tend to repudiate the dominant orthodoxy in extant literature, which views political parties as central to the deepening of democratic values, culture and ideals. The paper seeks to understand the aberration of the Nigerian context by isolating the rationale behind the peculiar functioning of political parties in Nigeria, which, instead of promoting democratic practice and consolidation, works at cross-purposes with those ideals. The paper interrogates the political context, processes, contradictions and challenges to the operation of Nigerian political parties, underscoring why they are rarely an agency for democratic stability and consolidation. Key questions raised include:

1 The term refers to the deluge of political crises that engulfed Western Nigeria in 1964/65, arising from incidences of election rigging which precipitated tremendous violence and eventually led, in 1965, to the collapse of the First Republic.

2 The First and Second republics were from 1960-1966 and 1979-1983, respectively. The Third Republic was aborted by the Babangida regime with the annulment of the 12 June 1993 presidential elections. 
- What is the context in which political parties are formed which denudes them of democratic ethos and practices?

- Can political parties led and controlled by retired military officers trained and acculturated in anti-democratic values internalise and promote democratic ideals?

- Can 'born-again' democrats (retired soldiers and their civilian protégés) with political pretensions to democratic credentials or ethos build and nurture democratic political parties?

- Can political parties bereft of internal democracy and consociational politics deliver and consolidate a democratic process?

- Finally, can democracy actually be built without democrats?

The paper begins with a conceptual and theoretical note on political parties and democracy. The second section examines the evolution of political parties in Nigeria in the Fourth Republic (1999 to today). The third part describes the impeachment saga which characterised the last two years of the Obasanjo regime and how this generated an intra- and inter-party crisis and general trepidation about the political process. The fourth section focuses on party primaries and how they promote undemocratic values, politics and practices. The fifth section takes up the issue of political violence, which has become intractable and endemic to party politics and threatens the nation's nascent democracy. Section six considers the electoral body and its relationship with the political parties in terms of its independence, neutrality and impartiality. The final section of the paper is the conclusion.

\section{CONCEPTUAL NOTES \\ POLITICAL PARTIES, DEMOCRACY AND DEMOCRATIC CONSOLIDATION}

The world has witnessed a phenomenal shift from authoritarian to democratic rule in the past 20 to 30 years, especially in the Third World and the countries of the former Eastern bloc. Thus, many more countries are democratic today than ever before (see, eg, Huntington 1991; O'Donnell, Schmitter \& Whitehead 1986; Adejumobi 2000). However, this was not the case at the beginning of the last century, when democracy was considered despicable.

The Aristotelean concept of democracy was that it was a form of polity in which every member of society was involved as a member of the governing council. However, in contemporary times democracy has come to be identified with the rulership of the people by elected representatives as against the notion of direct participation in the Aristotelean sense. Representative democracy is, therefore, the mode of modern democratic polity. 
It is necessary to distinguish between democratic ideals, democratic institutions and democratic practice in order to gauge effectively democratic accomplishment and consolidation (Przeworski et al 2000). Democratic ideals are the normative and constitutive values of the polity. They include such principles as freedom of expression, uncensored participation of the people in the determination of their destiny, equitable distribution of power, public accountability of elected representatives, and so on. These ideals have tended to govern not only political values but also such other socio-economic values as interpersonal relations, the market, and so on.

Democratic institutions are those supportive structures that are needed to provide the framework for democratic practice towards achieving the goal of democratic ideals. They include constitutionally safeguarded rights, an independent and effective judiciary, independent media, efficient electoral and party systems, an effective parliament, and participatory local governance, all prerequisites for democracy. In other words, without them, democracy is unattainable.

Democratic practice is the actual exercise of the principles of democracy. The effective practice of democracy is contingent on political participation, public awareness, robust opposition, an active civil society, and the nature of political parties. In other words, democratic practice suffers where democratic institutions are not entrenched and where there is an absence of robust opposition, active civil society and public awareness (Przeworski et al 2000).

Competition or contestation is regarded as essential to democracy - for any regime to be regarded as democratic it must allow some, even if limited, guaranteed competition among conflicting views, interests and ideologies. To Przeworski et al (2000) contestation involves three features: ex-ante uncertainty, which means some positive possibility that at least one member of the ruling coalition will lose in a particular round of elections. Uncertainty here is not synonymous with unpredictability. All that is required for outcomes to be uncertain is that it is possible for some incumbent parties to lose. The next feature is termed ex-post irreversibility - the assurance that whoever wins an election will be allowed to assume office. Outcomes of elections must be irreversible under democracy even if the opposition or a less popular party wins in a free and fair contest. Another feature of democratic competition is repeatability. Elections must be periodic. Whoever wins the current round of elections must not use office the power of incumbency - to impede the chances of other competing political parties in subsequent rounds of elections.

Przeworski et al further argue that democracy is government pro tempore. All political outcomes must be temporary; losers do not forfeit the right to compete in the future, to negotiate, to influence legislation, to pressure the bureaucracy, or 
to resort to the courts. Even constitutional provisions are not immutable as rules too can be changed. Democracy is a regime in which those who rule are elected through competitive elections. It affords office-holders the authority to exercise governance free from the legal constraints of having to report or answer to a power not constituted by the electoral process. Thus, governmental responsibility to voters is a defining feature of democracy.

Alternation in office constitutes prima facie evidence of contestation, and contestation occurs where the opposition is likely to win office as a consequence of an election. To Przeworski democracy is a system in which parties lose elections. The democratic process is protected by constitutional provisions and supported by institutions and structures, which work together to deepen democratic culture and ideals.

\section{POLITICAL PARTIES AND THE DEMOCRATIC PROCESS}

Political parties drive the democratic process as well as democratic consolidation. Democracy is sustained as a form of government through participation in competitive and periodic elections on the platform of political parties. Periodic and competitive elections help strengthen democracy through the process of institutionalisation (Akinbobola 2003). Political parties are an integral part of the process of institutionalising democracy and, as Agbaje (2004) argues, it is difficult to conceptualise democracy either in theory or in practice without the existence or prevailing atmosphere of participation.

Guaranteed periodic electoral competition, characterised by ex-ante uncertainty and ex-post irreversibility strengthens the democratic process by establishing a pattern of regime change which is not subject to arbitrary intervention. ${ }^{3}$ The only platform through which periodic electoral competition is contested is the party system. It is political parties that present alternative electoral options to the voting public by providing contending manifestoes and worldviews. Political parties make electoral competition possible, reinforcing the peculiar characteristic of the certainty of electoral loss and the simultaneous irreversibility of such an outcome.

When this pattern has been established and practised for a considerable time, the democratic process can be characterised as consolidated, well able to withstand pressures that would otherwise have caused it to falter or be reversed (see, variously, Beetham 1994; Huntington 1991; Linz 1990; O’Donnell, Schmitter \& Whitehead 1986).

3 Any such modification of the established pattern must be sanctioned by Parliament after being subject to constitutionally provided amendment procedures. 
However, for political parties to be effective as instruments of democratic consolidation they must exhibit the following features: they must be composed of like-minded people whose worldviews are similar, or, at least, amenable; they must promote a set of programmes embodying the vision, mission and manifesto of the party and designed to meet the needs of the public; they must be massbased, which helps to legitimise them; they must have evolved gradually and systematically over time, with identifiable leaders who constitute their rallying points; they must exhibit characteristics of internal democracy in their operations. This last point is central to understanding why Nigerian political parties have not served as agencies of democratic consolidation. The parties are mostly internally weak, with democratic deficits in their conduct and operations.

Contemporary political parties in Nigeria largely exhibit features that are at variance with acknowledged or orthodox norms of party formation, conduct and functioning. The parties are mostly made up of 'strange bedfellows', ${ }^{4}$ whose only convergence is the overwhelming desire to control the apparatuses of government. The parties lack any identifiable ideological underpinning, which should be the motivating force of their activities and from which they are expected to derive their manifesto. Again, lack of ideology is largely responsible for the shifting party allegiances so characteristic of party politics in Nigeria. ${ }^{5}$

The parties lack iconic features like charismatic leadership and ideology and are equally denuded of internal democratic norms. In Nigeria, a small clique largely controls the parties. Although the members of the clique come from diverse backgrounds, the dominant social or occupational group is made up of retired military officers, policemen and para-military agencies. This group, the result of long years of military rule, has, over the years, amassed stupendous wealth, vast political networks and connections, and political allegiances, which they deploy in the arena of party politics (Adejumobi 2002; Adekanye 1999). This partly explains some of the anti-democratic tendencies of those parties.

In addition, the process leading to the institution of the present republic was rushed; hence the political parties that emerged were hurriedly contrived rather than gradually evolving, allowing for acceptability and legitimacy.

4 The G54, which formed the nucleus of the PDP at its formation, included pro-democracy activists (Bola Ige, etc), retired military officers (Samuel Ogbemudia, Anthony Anenih, Buba Marwa, etc), and political jobbers like Jerry Gana, Iyiorcha Ayu, etc. The same is true of the APP (later ANPP), the AD and other parties. The case of the newly registered AC is far more intriguing: it is made up of splinter groups from the PDP, ANPP, AD, Justice Party and Action Alliance; a potpourri of elements) (see ThisDay 25 September 2006).

5 Politicians change allegiance at an alarming rate; the former vice-president moved to the AC from the ruling PDP when he was denied the opportunity to stand as the party's presidential candidate (see ThisDay 26 November 2006, p 1). There were other cases of defections (see Vanguard June 26 2006, p 12). 


\section{THE EVOLUTION AND NATURE OF POLITICAL PARTIES IN NIGERIA}

(1999-2007)

Following the annulment by the Babangida military regime of the 12 June 1993 presidential election results there emerged a groundswell of agitation, spearheaded by civil society, first, for the validation of those results and eventually for a return to democratic rule. The Abacha regime, which took over from the interim national government, initially vacillated, but ultimately capitulated and agreed to a transition programme which would, in effect, transform him into a civilian president. However, in 1998 General Abacha died suddenly and General Abubakar became head of state.

Abubakar immediately embarked on a programme of transition to civilian rule, culminating in the swearing in, on 29 May 1999, of a democratically elected president. The transition was rather short, hence, the political parties that emerged were hurriedly conjured up, lacking in any form of ideology and well articulated interests and programmes. Three major parties emerged to contest the elections, namely, the Peoples Democratic Party (PDP), the All Peoples Party (APP) (later the All Nigerian Peoples Party - ANPP) and the Action Congress (AC).

All three were reincarnations of the dominant parties of the Second and Third republics. The PDP was the National Party of Nigeria (NPN) of the Second Republic and is, as Agbaje \& Adejumobi (2006, p 35) have noted, a party of retired military officers, buccaneer capitalists, old politicians of conservative NPN stock and former technocrats. The AD metamorphosed from the pan-Yoruba sociocultural group (Afenifere), the surviving arm of the Action Group (AG) and the Unity Party of Nigeria (UPN) of the First and Second republics, laying claim to the Obafemi Awolowo political dynasty. The ANPP has its origin and support base in the north, relies on religious and ethnic symbols for political support, and has, among its leadership, apologists for the Abacha regime, retired soldiers, and ethnic irredentists. The nature of these parties was succinctly captured by Lewis (2003, p 134).

The nebulous party system has little to do with any distinct ideologies, strategies or sectional appeals. The major parties are relatively diverse in their leadership and constituencies, but remain focused on elite contention and patronage. Ethnicity is still a crucial vehicle for political mobilization. Personalities and clientelist networks predominate; internal discipline is weak; internecine battles are common. Politics is 'winner-takes-all' because public office is still a high road to personal enrichment by dubious means. 
These dominant parties are mainly elitist rather than mass-based. Party leadership and recruitment for elective positions are a function of social status. They exhibit a general lack of internal democracy, which reflects internal crisis and disorder. Their management of issues and events does not reflect mass-based considerations but the articulated interests of the party leadership. This is, unfortunately, a reflection of a countrywide disregard for the voting public.

A major trend in the PDP was the increasing personalisation of the party by former president Olusegun Obasanjo during his second term of office (2003-2007). Obasanjo reconfigured the party and installed his protégés at its helm. The PDP virtually became the president's personal political machine. As General David Jemibewon, one of the founders of the PDP, lamented: 'The initial hope, the initial vision, the initial objective of the PDP seems to have been lost. The founding fathers of the PDP did not imagine what is happening today would happen. And so, there were no kind of anticipated remedy against Obasanjo having a tight grip of the party' (Sun Newspaper 21 July 2007).

As later events revealed, Obasanjo needed to have total control of the party in order to pursue his abortive third-term agenda. ${ }^{6}$

Between 1999 and 2003 three parties (PDP, APP and AD) registered by the Independent National Electoral Commission (INEC) dominated the political space in Nigeria. They were the only parties that took part in the 1999 general elections, as the requirements for registration were very stringent. However, in 2002, three additional parties were registered out of a pool of 33 seeking registration. They were the United Nigeria People's Party (UNPP), the All Progressive Grand Alliance (APGA), and the National Democratic Party (NDP). The basis for INEC's decision was unclear, and dozens of smaller political associations challenged their exclusion in court. The Supreme Court in November 2002 ruled in favour of the associations by nullifying some of INEC's guidelines for party registration. Hence, the political space became liberalised and 27 new parties were registered in December 2002 to contest the 2003 general elections. At the time of the 2007 general elections there were 50 registered political parties in the country.

Another prominent feature of political parties in Nigeria, especially the PDP and the ANPP, is the presence of the retired military. The military had ruled Nigeria for much of its existence as an independent state (1966-79, 1983-99). The global wave of democratisation forced it to relinquish power, which it did by replacing the uniform of the general with mufti. In other words, after their retirement military officers were transformed into civilian political leaders. This mere change

6 Obasanjo wanted to remain in office beyond the constitutionally allowed two terms and attempted to have the Constitution amended to allow for a third four-year term. However, the combined forces of civil society, some segments of the political class and the media, aborted the agenda. 
of form without substance has grave implications for democratic consolidation. From the executive at all levels to the legislature, retired military, police, and paramilitary officers hold sway.

Even in the hierarchy of the political parties retired officers hold key and sensitive leadership positions. The present national chairman and a vice-national chairman of the PDP, Chief Amadu Ali and Chief Olabode George respectively, are retired military officers. The immediate past president, Chief Olusegun Obasanjo, is a retired military officer, as is his deputy, Atiku Abubakar, formerly a customs officer. The ANPP's presidential candidate in both the 2003 and the 2007 elections, Major-Gen Muhammadu Buhari, is also a retired military officer and former head of state.

The present president of the Senate, Major-General David Mark, and many other elected representatives are retired military, police and paramilitary officers, men well schooled in the military tradition of command and control and who regard democratic niceties as unnecessary and diversionary encumbrances. They are not given to accepting dissenting opinions and view everything in the military tradition of the garrison.

Thus, the political space and the parties they lead have become acculturated to military values and politics. ${ }^{7}$ In August 2007 the European Union Observer Mission to the April 2007 general elections released and presented its final report to the political leadership and the general public. However, Gen Mark's response was to caution the EU team not to destabilise the country. For him, the report was inimical to peace, order and stability, and was therefore objectionable. David Mark could not appreciate the value of objective and scientific evaluation of the election or the necessity for a democratic climate that allows for critical views. His military notion of peace and order influences his conduct and behaviour as an elected official in a democratic dispensation.

Another recurring element in the party system is the hydra-headed issue of the political barons, otherwise referred to as political 'godfathers'. Politics is a very expensive venture, which many aspiring politicians can ill afford. The Electoral Act 2006 stipulates limits on electoral expenditure by candidates - the maximum sum that may, by law, be committed to presidential electoral campaigns is $\$ 500-\mathrm{m}$. In a country where more than 60 per cent of the people live below the poverty line, and the middle class has been all but wiped out, it is extremely difficult for many aspirants to come up with the wherewithal necessary for such

7 Speaking about what seems to be the military nature of former president Obasanjo's administration former vice-president Atiku Abubakar, who fell out with the president on grounds of irreconcilable political ambition, noted that the Obasanjo government 'is a government that does not respect the rule of law, that wants to govern this country autocratically... a dictatorship in a civilian and democratic garb' (The Guardian 16 February 2007, p 1). 
a campaign. Lesser limits are set for aspirants for gubernatorial, parliamentary and other positions. This problem appears to be solved by the ominous presence of political godfathers political entrepreneurs who make their largely ill-gotten wealth available to politicians in return for state patronage. The godfathers see their involvement as a purely business investment which must yield multiple returns. According to Agbaje \& Adejumobi (2006, p 39) the political barons 'hold no elective offices or party positions. They often constitutee informal leaders who are more powerful than the party chiefs and formal office holders. They sponsor candidates, corrupt election officials ... they are virtual kingmakers.' The relationship is mutual, as these political barons hope to recoup their investment with substantial interest when their protégés assume office.

However, the godfather-protégé relationship is essentially conflict ridden. Just as the client in power seeks to assert himself and pursue the objectives set out in the statement of intent presented to the electorate, the political entrepreneur, whose sole aim is to maximize investment, insists on his payoff. This has frequently led to conflict and crises (Agbaje \& Adejumobi 2006). The problem is almost nationwide but is more prevalent in Anambra and Oyo states, where the then governors lost their positions because of the overwhelming influence of the godfathers. ${ }^{8}$ This characteristic of the dominant political parties threatens the democratic project in Nigeria.

\section{PARTY CRISES AND THE IMPEACHMENT SAGA}

Knowledge of the political environment in which parties operate and elections are conducted is germane to an understanding of the capacity, activities and limitations of those parties and the intricate politics of party relationships. One such example was the political impeachments which characterised the Obasanjo presidency from 2004 to 2006.

There was an avalanche of impeachments and threats of impeachment, especially of elected governors. This reflected deepening intra-party and interparty crises and the struggle for power by dominant political forces. When the friction that triggers the impeachment is intra-party it is either premised on factional battles within the party or the urge by a powerful force to tilt the balance of power in its favour in the state. However, when it is inter-party it is mostly triggered by the PDP, the ruling party at the federal level, and aimed at weakening opposition parties who control the state, as a pre-emptive move towards capturing

8 Governor Ladoja was reinstated following the intervention of the Court (Independent 10 December 2006). However, he faced a considerable threat to his position throughout his tenure as a result of his estrangement from his godfather, Lamidi Adedibu. Governor Obi of Anambra state also regained his seat. 
the state in the next election. While the Constitution provides for impeachment of elected officials this step should only be taken in cases of grave misdemeanour. However, the constitutional provision was flagrantly abused by impeachments that were vindictive, unprocedural or illegal (see Adejumobi 2006; 2007).

In most cases the presidency was deeply involved. The state anti-corruption agency, the Economic and Financial Crimes Commission (EFCC) was deployed to harass, intimidate, cajole and blackmail members of the houses of assembly of the affected states into initiating impeachment proceedings against their governors. In the states in which impeachment proceedings were seen through, the procedures fell short of the constitutional provisions. ${ }^{9}$ For instance, Governor Ladoja of Oyo State was impeached by fewer than the two-thirds of the members of the House of Assembly required by the Constitution. The case of Plateau State reflects a graver violation, with only six members (less than $20 \%$ of the house) sitting (at 6.30am) to impeach Governor Dariye. ${ }^{10}$ Governors were also impeached in Anambra, Ekiti, and Balyesa states.

The principles of the rule of law and checks and balances integral to the democratic process were ignored in many of the impeachment cases. While some of the state governors may have committed impeachable offences, as later revelations confirmed the impeachment agenda facilitated by the presidency was driven more by political motives than by a genuine interest in punishing erring elected officials. The subversion of the rule of law and due process, which characterised the exercise in many states, was premised on the presidency's wish to remove certain governors and instal its protégés in an acting capacity in order to control the states for personal political purposes.

The consequences of the impeachment saga for political parties were fourfold. First, it absorbed the attention and energies of the main actors within the parties, diverting their focus from urgently needed internal party organisation and planning for the elections. Second, it reinforced the non-adherence to due process and the rule of law characteristic of the party system in Nigeria. Third, it created fear, apprehension and tension in the political milieu, decelerating preparations for the elections. Fourth, it created an uneven playing field for actors between and within political parties as those who were in government at the federal level, especially the presidency, were able to use the EFCC to cajole, intimidate and subdue other political forces within and outside the ruling party.

9 State chief executives who passed through the dark tunnel of impeachment amidst controversy include Governor Alamieyesiegha of Bayelsa State; Chief Rashidi Ladoja of Oyo State; Ayo Fayose of Ekiti State; Joshua Dariye of Plateau State; Mr Peter Obi of Anambra State and Boni Haruna of Adamawa State, whose impeachment proceedings were stopped by the courts.

10 It is instructive to note that the Court reinstated almost all the impeached governors, which is a reflection of the unconstitutionality of the process by which they were impeached. 


\section{PARTY PRIMARIES}

Primaries designed to select party flag bearers in elections have always been controversial and acrimonious, with most parties exhibiting grossly undemocratic tendencies and disregard for popular choice. In the 2003 elections only a few parties held primaries (Akinbobola 2003) and even fewer did so for the 2007 elections, signalling a growing tendency towards anti-democratic practices.

The charade was beamed live on national television, with party flag bearers being anointed rather than elected. ${ }^{11}$ The immediate consequence was massive defections from virtually all the parties. The situation in the PDP was particularly intriguing. Because of his ongoing feud with the former president, then incumbent vice-president Atiku Abubakar was prevented from running for the presidential candidacy. Long before the party's presidential primaries the president and his political cronies repeatedly maintained that the vice-president would never be allowed to run on the party's platform. In pursuit of this goal the president dissolved the party's executive committees, directing members to seek reregistration. In the process, those considered to be either supporters of or sympathetic to the vice-president were denied registration. Elections for positions of leadership within the party were devoid of credibility or democratic practice. Consequently, the president was able to gain effective control of the party and frustrate the presidential ambitions of his deputy. The vice-president was forced to defect to another party, the Action Congress (AC), in order to pursue his presidential ambition.

The situation was similar in almost all the other parties. In the ANPP almost all the aspirants melodramatically withdrew from the race in recognition of the 'apparent' qualities and capability of General Buhari, the preferred candidate of the leadership of the party. In the AC, Atiku Abubakar was 'adopted' unopposed in the presidential party primaries, reflecting not consensus, but overt political control by the dominant forces in the party.

Stage-managed primaries were not limited to the presidential level, they were acrimonious and conflictual at all levels, leading to deep schisms and realignments. A case in point is the AC gubernatorial primary in Lagos, where the leadership of the party lent its weight to a particular aspirant (Babatunde Fashola), who eventually emerged as the party candidate. The other aspirants, feeling short-changed, claimed the primary was manipulated to produce pre-

11 Almost all the serious contenders were coerced into stepping down in favour of candidates preferred by the party leadership. Many serious presidential aspirants in the PDP, who had mounted intensive national campaigns, 'surprisingly' stepped down for Governor Yar'Adua, whose aspirations before the primary did not appear to be serious. 
determined results and left the party for other parties, where they secured tickets to contest the election. Interestingly, in the parties they decamped to, the candidates adopted the same anti-democratic method to secure their nomination that they had decried in the parties they had left. Very few parties held primaries and, where they were held, they were mere charades, devoid of basic democratic principles and ideals.

The most bizarre primaries were those in the PDP, whose party leadership discounted the results and arbitrarily imposed candidates who either had not won or did not stand at all. The party leadership claimed it was 'supreme' and members could not challenge its actions. To give just two examples: in Imo State, Senator Ararume, one of 21 contestants, had won the gubernatorial primary. Ararume reportedly polled 2 061, followed by Chief Hope Uzodinma with 1649 votes. Since both results fell below the party's requirement of 50 per cent for a clear winner, it was expected that a run-off election would be organised. However, disregarding the outcome, the party leadership in the state announced Chief Tony Ezenwa, who had come fifth in the vote, as the party's flag bearer.

INEC published Ararume's name as the aspirant with the highest number of votes but, in a dramatic turn of events, the party leadership announced Charles Ugwu (who had been in fourteenth position) as its consensus candidate (Guardian 11 February 2007, p 55). Ugwu, a former president of the Manufacturers Association of Nigeria, had supported President Obasanjo's aborted third-term bid. Many therefore believed that the president was rewarding a 'loyalist' with the party's gubernatorial nomination.

Senator Ararume's challenge to the party's decision was upheld by the Supreme Court, which directed INEC to list him as the party's gubernatorial candidate; thereafter the party leadership expelled Ararume. Complying with the Supreme Court decision INEC listed Ararume as the party's candidate, but the party worked against him to ensure his defeat at the polls.

There was a similar episode in Rivers State where Rotimi Amaechi, former Speaker of the state House of Assembly, was declared winner. The party hierarchy, however, decided otherwise, putting forward Celestine Omehia as the party candidate. The party won the gubernatorial election and Amaechi instituted legal action. In October 2007 the Supreme Court, in a landmark judgement, ruled in favour of Amaechi and directed that he should be installed as the elected governor. The party has since expelled Amaechi for anti-party activities deriving from this legal action.

Nigeria's political parties are fraught with internal crises and conflicts. From the PDP to the ANPP, AC and AD, and even the smaller parties like the All Progressive Grand Alliance (APGA), factionalisation and alignments based on almost irreconcilable differences have torn the parties apart. All three major parties 
have suffered balkanisation, with factions splitting away from the parent party to merge with other splinter groups to form new parties. The People's Democratic Movement (PDM) caucus of the PDP pulled away to merge with a splinter group from the $\mathrm{AD}$ to form the Action Congress (AC) and another caucus, under the leadership of Audu Ogbe and Solomon Lar, two former national chairmen of the PDP, left the party. ${ }^{12}$

The problem is not limited to the PDP, indeed, it mirrors a general tendency. Congresses of parties convened to elect national leaders have ended up being charades where every principle of civilised conduct and tenet of democracy has been set aside.

The undemocratic nature of these primaries and the attendant unpopular choices of party flag-bearers contributed in no small measure to the spate of violence experienced across the country during the run-up to the 2007 elections. ${ }^{13}$

\section{PARTIES AND POLITICAL VIOLENCE}

The undemocratic tendencies of party politics resulted in an increase in politically motivated violence and assassinations. Indeed, the rate of political assassinations assumed proportions never before known in the country. The spate of arson, thuggery, unconstitutionality and general insecurity was, perhaps, second only to the operation wetie ${ }^{14}$ era in the old Western Region, when political violence was rampant and endemic (Kehinde 2007).

The party system contributes in no small measure to the escalating political violence. The zero-sum nature of electoral competition, which leaves no room for coalition and cooperation, propels parties to consider elections as 'must win'. The stakes are simply too high for losing an electoral contest to be considered an option. Thus, a range of devices is employed to outsmart fellow competitors in order to influence results. Since there can only be one winner there will always be losers; the losers denied access to state power become frustrated, which leads to aggression and violence.

12 The AC emanated from a fusion of six political parties - the Advance Congress of Democrats (ACD), a faction of the Alliance for Democracy (AD), led by Chief Bisi Akande; the Justice Party (JP), a faction of the All Nigeria Peoples' Party (ANPP); the All Peoples' Congress (APC); the Progressive Party Alliance (PPA); the Solomon Lar-led faction of the PDP; and, recently, the Action Alliance (AA) (ThisDay 25 September 2006, p 19).

13 Everywhere, there was wanton destruction and anxiety filled the land (Sunday Sun 19 November 2006, p 5).

14 Operation wetie (operation 'wet it') was the dousing of houses and properties with combustibles by political opponents at the height of the anarchy engendered by political instability in the Western Region following the electoral fraud of 1965. 
The build-up to the general elections of April 2007 was particularly violent. The determination of the PDP to stage a clean sweep and the unwillingness of the other parties to be sidelined made violence - both inter and intra-party -inevitable. The polity was literally ablaze and police and other security agencies were compromised, as they became willing tools in the hands of politicians, especially those of the PDP, who employed them to perpetrate crimes and to look away when their goons were in action. As a result few perpetrators of violence have been brought to justice by the state security agencies. The assassination of serving Minister of Justice and Attorney General Bola Ige reveals the heightened level of political and social insecurity in the country.

The intention was to eliminate or intimidate potentially formidable opponents from contesting elections. In Ogun State Dipo Dina and Ibikunle Amosun, leading opposition politicians, were severally harassed and attacked in the build up to the elections. The state governor, Gbenga Daniels, employed state apparatus to intimidate key opposition figures. Dina was arrested and detained by the police on trumped up charges. He and Amosun were physically attacked. The senatorial candidate for the ANPP in Ogun East Senatorial district, Lanre Tejuosho, standing against Iyabo Obasanjo-Bello of the PDP, daughter of the former president, barely escaped assassination when assailants attacked him. In Oyo State, perceived opponents of the PDP gubernatorial candidate and their supporters and families were targets of violent attack and many had to relocate to escape assassination.

Intra-party violence was also rife. In Ekiti and Lagos states, Daramola and Funsho Williams, leading PDP gubernatorial aspirants, were assassinated in 2006 and thus far no one has been prosecuted or brought to justice for the crime. In Lagos state, electoral campaigns by PDP gubernatorial aspirants were theatres of violence, death, and destruction.

The scope of political violence is not limited to the parties, but extends to the general public. The violence unleashed in Anambra in the wake of the irreconcilable differences between Chris Ngige and his political godfather, Chris Uba, is a case in point. From Awka to Onitsha, to Nnewi and Nsukka, the whole state was involved. The state governor's lodge was attacked and set ablaze by political hoodlums, allegedly on the instruction of Chris Uba. The governor, Chris Ngige, had to go into hiding for fear he would be killed. The unending political crisis in Oyo State, where violence has taken over reason, is a direct fallout from the intraparty wrangling occasioned by Ladoja's assertion of independence from the stranglehold of his erstwhile godfather, and the acclaimed strongman of Ibadan politics, Lamidi Adedibu. At the height of this face-off, Ibadan and other major cities in the state became battlefields.

While the parties signed a code of conduct committing them to non-violent campaigns, most did not abide by or respect the spirit and letter of the code. 
Violence reigned freely before, during, and after the 2007 elections, either in an attempt to forestall the rigging of elections or to perpetrate rigging, or to protest against it. More than 500 people were reportedly killed during the elections.

\section{INEC AND THE ELECTORAL PROCESS}

INEC has the primary responsibility for managing elections in Nigeria. Among its responsibilities are: registration and monitoring of political parties, voter registration, delineation of constituencies, conduct of elections, and declaration of election results. To perform these responsibilities effectively the electoral body must be truly independent and impartial. However, the experience in Nigeria indicates otherwise. As Agbaje and Adejumobi (2006, p 30) note, 'over the years, the autonomy and capacity of this body has been suspect. This is reflected in its endless renaming and restructuring by successive governments ... the problems of legitimacy and credibility are embedded in the institutional history'.

INEC, like its predecessors, has been unable to engender public confidence in the electoral process, or organise credible and transparent elections. Those who win elections, or, rather, those who rig their way into power, seek to rule in perpetuity, and those who lose elections wage unending 'wars' to gain power. In essence, power is not achieved by means of a democratic process but by the ability to out-manoeuvre others and perpetuate a hold on power, with the connivance of INEC.

INEC has neither political nor financial autonomy; all it has is relative administrative independence to recruit and discipline its staff (Adejumobi 2007). The members of the commission are appointed by the president and its financing is determined by the executive. Thus, the ruling party often has considerable leverage in influencing and compromising the integrity of the commission.

The ruling party, the PDP, frequently uses its majority status in the National Assembly as well as its hold on INEC to manipulate the electoral process in its favour. The Electoral Act 2006, initiated by the executive and ratified by a PDPled National Assembly, tilts the scale in favour of the PDP. For instance, the Act provides a formula for distributing the money to the parties. Section 90 of the Act stipulates that the National Assembly may approve a grant for disbursement to political parties contesting elections. Though the law delegates to the INEC the responsibility for sharing out the money, as did the 2002 Act, the sharing formula has changed. Only 10 per cent of the total amount disbursable is distributed equally among all the parties, while the remainder 90 per cent is to be shared 'in proportion to the number of seats won by each party in the National Assembly'. This situation favours the PDP and further sharpens competition and struggle among the parties for electoral victory at all cost. 
Historically, funding has been a lingering issue in party politics in Nigeria. In both the First and Second republics (1960-1966, and 1979-1983 respectively) the issue of party financing was a major factor in political corruption. Many functionaries and political office holders 'corruptly enriched' their parties from state funds. After the collapse of the Second Republic the succeeding military junta, the Buhari regime, jailed many politicians for allegedly siphoning off state funds to finance their parties. Although there are unambiguous legal stipulations for party financing, many parties, especially the ruling party, flout them with reckless abandon.

INEC exhibited gross partisanship in handling electoral matters, becoming enmeshed in issues that were outside of its scope and, in the process, displaying its partisan preferences. Acting on the promptings of the EFCC and the presidency it disqualified some candidates, including former vice-president Abubakar, from standing, citing allegations of corruption against them by the EFCC. However, the Electoral Law vests the power to disqualify candidates in the courts. Many of those disqualified were either leading opposition candidates or PDP candidates considered threatening to the interests of the leadership of the party.

In a landmark judgement in April 2007 the Supreme Court declared the disqualification of the candidates null and void and directed INEC to restore their names to the ballot papers. However, the first set of gubernatorial and parliamentary elections had already been conducted by the time the ruling was handed down, thus denying those disqualified their legitimate right to contest the elections.

\section{CONCLUSION}

Political parties, in a conventional sense, are the major agency for the evolution and nurturing of democratic ethos, norms and practices in a liberal democratic system, hence, they are the vehicle for democratic consolidation and progress. The Nigerian experience confounds that logic. In Nigeria political parties limit civic participation in the political process; they lack a clear ideological focus or worldview, articulating blurred agendas; and they are perverted in terms of their functioning, processes and relationships. The consequence is that Nigeria's democratisation process is faced with serious threats of political reversal as entrenched authoritarian values persist.

The dominant political parties in Nigeria connect neither with the people nor with organised interests like labour, human rights groups, and student movements. They are basically tools for power appropriation, material aggrandisement, and undemocratic practices. The future of democracy in Nigeria lies in reconfiguring the party arena, to allow for greater political space for smaller political 
parties like the National Conscience Party (NCP) and the Peoples' Redemption Party (PRP), which show some promise in terms of their programmes and agendas and their mass appeal to grow and gain prominence. This will require a contestation of the political space with the dominant forces, and the better organisation of those smaller parties to connect effectively with mass-based organisations and people in society. In other words, a reconfiguration of the political space and the political elite in Nigeria.

\section{REFERENCES}

Adejumobi, S. 2000. 'Elections in Africa: A Fading Shadow of Democracy?' International Political Science Review 21(1).

-2002. 'The Military and the National Question'. In S Adejumobi and A Momoh (eds). The National Question in Nigeria: Comparative Perspectives. Aldershot: Ashgate.

2006. 'Impunity, Impeachment Saga and our Democracy'. Guardian, Lagos, 3 December.

-2007. 'When Votes Do not Count: The 2007 General Elections in Nigeria'. Nordic Africa Institute News Bulletin 2.

Adekanye, B. 1999. The Retired Military as Emergent Power Factor in Nigeria. Ibadan: Heinemann.

Agbaje, A. 2004. 'Prospects for the Fourth Republic'. In E Gyimah-Boadi (ed). Democratic Reforms in Africa: The Quality of Progress. Boulder: Lynne Reinner Publishers.

— \& S Adejumobi. 2006. 'Do Votes Count? The Travails of Electoral Politics in Nigeria'. Africa Development XXXI(3).

Akinbobola, A. 2003. 'The Nigerian Political Party System and the 2003 General Elections'. In R Anifowoshe \& T Babawale (eds). 2003 General Elections and Democratic Consolidation in Nigeria. Lagos: Friedrich Ebert Stiftung.

Anifowoshe, R. 2003. 'Theoretical Perspectives on Elections'. In R Anifowoshe \& T Babawale (eds). 2003 General Elections and Democratic Consolidation in Nigeria. Lagos: Friedrich Ebert Stiftung.

Beetham, D. 1994. 'Conditions for Democratic Consolidation'. Review of African Political Economy 60.

Burke, E. 1968 [1790]. Reflections on the Revolution in France (C C O'Brien (ed)). Harmondsworth: Penguin.

Da Costa, G. 2007. 'Nigerian Parties Resolve to Curb Violence'. VOA News $<$ www.voanews.com/english/2007-02-08-voa19.cfm>.

Diamond, L. 2004. 'Thinking about Hybrid Regimes'. In P O' Nell \& R Rogowski (eds). Essential Readings in Comparative Politics. New York: Norton \& Company, Inc. 
Guardian, Lagos, 11 February 2007.

16 February 2007.

26 August 2007.

Haywood, A. 1997. Theories of Politics. London: Macmillan.

Heller, P. 2000. 'Degrees of Democracy: Some Comparative Lessons from India'. World Politics 52.

Huntington, S. 1991. The Third Wave: Democratisation in the Late Twentieth Century. Oklahoma: University of Oklahoma Press.

INEC $<$ www.inecnigeria.org $>$

IFES-Nigeria. 2006. Democracy at Large: Political Finance Newsletter 7. Abuja.

Jinadu, L. A. 1997. 'Matters Arising: African Elections and the Problem of Electoral Administration'. African Journal of Political Science 2(1).

Kehinde, M O. 2007. 'Democracy and Political Violence in Nigerian Federalism'. In F Omotoso (ed). Readings in Political Behaviour. Ado Ekiti: UNAD Press.

Lasham, C. 2006. 'Electoral Act 2006 and Political Finance'. Democracy at Large: Political Finance Newsletter 7. Abuja.

Lewis, P. 2003. 'Nigeria: Elections in a Fragile Regime'. Journal of Democracy 4(3). Linz, J. 1990. 'Transitions to Democracy'. Third World Quarterly, Summer.

O’Donnell, G P, C Schmitter \& L Whitehead (eds). 1986. Transitions from Authoritarian Rule Vols 1-4. Baltimore: Johns Hopkins University Press.

Przeworski, A, M Alvarez, J A Cheibub \& F Limongi. 2000. Democracy and Development: Political Institutions and Wellbeing in the World, 1950-1990.

Cambridge: Cambridge University Press.

Sun, Lagos, 21 July 2007.

ThisDay, Lagos, 25 September 2006.

25 November 2006.

26 November 2006.

Vanguard (Lagos), 26 June 2006. 